\title{
PERAN GURU DALAM PEMBELAJARAN PENDIDIKAN AGAMA ISLAM BERWAWASAN MULTIKULTURAL
}

\author{
Nur Fauziah \\ Guru Pendidikan Agama Islam SMK Negeri 1 Kademangan Blitar
}

\begin{abstract}
In the context of religious education, multicultural paradigm is the main foundation organizing of teaching and learning process. Religious education requires more than just curriculum transformation, it also changes in the religious perspective of an exclusive view into multicultural outlook, or at least to maintain the views and attitudes of an inclusive and pluralism. Realized or not, these groups are culturally and ethnically distinct advance religion, often the victims of racism and impact of the larger society. Therefore, Islamic religious education as a discipline which include the national education have a duty to inculcate awareness of the differences, considering Islam is the majority religion in Indonesia, the postscript is a multi religious country. Growing awareness of religious diversity, required in the new format in the Islamic religious education with teaching multicultural vision. Islamic religious education learning brings a multicultural vision of dialogic approaches to inculcate awareness of living together in diversity and difference. This learning is built on the spirit of equality relationships, mutual trust, mutual understanding and appreciating the similarities, differences and uniqueness, as well as interdepedensi. This is an innovation and an integral and comprehensive reform in charge of religious education that is free of prejudice, racism, ambiguous and stereotyping. Religious education provides recognition of multicultural vision of plurality, learning tool for cross-border encounters, and the indoctrination transform to dialogue.
\end{abstract}

Keywords: Teacher, Multicultural, PAI Learning.

\section{A. Pendahuluan}

A multicultural country merupakan sebutan yang sangat cocok untuk Indonesia.

Betapa tidak, keragaman agama dan kepercayaan, suku yang terpencar di lebih dari 17.000 pulau, keunikan bahasa daerah yang menempati jumlah terbanyak di dunia (lebih dari 500 bahasa daerah) selain itu penduduk Indonesia juga menganut agama dan kepercayaan yang beragam seperti Islam, Kristen protestan, Katolik, Hindu, Budha, Kong Hu Chu serta berbagai aliran kepercayaan (Yaqin, 2005:4). Sejumlah keragaman tersebut merupakan potensi dan keunikan yang dimiliki oleh bangsa Indonesia sebagai bangsa yang besar. Akan tetapi keragaman dan keunikan tersebut selama ini tidak mendapatkan tempat dalam proses pembangunan bangsa, bahkan diakui atau tidak keragaman sering menjadi penyebab timbulnya persoalan yang 
dihadapi bangsa ini sekarang, seperti kolusi, korupsi, nepotisme, premanisme, perseteruan politik, kemiskinan, kekerasan, seperatisme, perusakan lingkungan dan hilangnya rasa kemanusiaan untuk menghormati hak-hak orang lain.

Sebenarnya, keberagaman dalam suatu komunitas bisa memberikan energi positif apabila digunakan sebagai modal untuk bisa bersama membangun bangsa dalam hubungan yang saling memberi dan menerima, dan sebaliknya apabila keberagaman masih dibingkai oleh penafsiran yang bersumber pada sebuah simbol yang mengikat atau menekan dimana sarat akan prasangka, kecurigaan, bias dan reduksi terhadap kelompok di luar dirinya, maka ia hanya akan menjadi bom penghancur struktur dan pilar kebangsaan (Hilmi, 2003:333).

Di satu sisi dengan keragamannya Islam berjasa bagi penciptaan landasan kehidupan bersama dalam konteks bermasyarakat, berbangsa dan bernegara dengan menawarkan norma-norma, sikap dan nilai yang dapat memperluas relasi damai di antara komunitas-komunitas etnik, budaya dan agama. Sisi yang lain menampakkan keragaman Islam juga dapat menyumbangkan api konflik dan ketegangan antar kelompok yang terus membesar.

Tantangan Islam tidak hanya sebatas pada konflik-konflik yang berdasarkan agama, tetapi juga tantangan globalisasi yang disadari atau tidak terus mendesak ke permukaan. Kehidupan modern menawarkan banyak pilihan. Siapapun yang hidup di Era IPTEK sekarang ini, tak terkecuali umat Islam, harus sepenuhnya menyadari ia hidup dalam ruang dan waktu yang tidak sama persis seperti 25 atau 50 tahun yang lalu. Internet atau dunia maya, telepon seluler, peralatan $\mathrm{Hi}$-Tech, dan Industri hiburan yang ramai telah menjadi makanan sehari-hari masyarakat.

Kehadiran Islam di tengah kehidupan berbangsa dalam masyarakat Indonesia yang beragam perlu diredefinisikan dengan menawarkan harapan dan perspektif keagamaan yang baru, bahwa Islam adalah seraut wajah yang tersenyum (smilling face of Islam), damai dan anti kekerasan (Baidhawi, 2005:44). Islam perlu memberi nuansa paradigmatik bagi rekonstruksi dan pembangunan karakter bangsa. Diperlukan strategi khusus dalam upaya menampilkan wajah baru Islam melalui berbagai bidang, seperti; sosial, politik, budaya, ekonomi dan pendidikan. Dunia pendidikan menjadi pilihan yang potensial. Pendidikan selain sebagai aktifitas transfer of knowledge juga merupakan media dan aktifitas membagun kesadaran, kedewasaan dan kedirian 
peserta didiknya, sebagaimana dikemukakan Freire bahwa pendidikan harus dianggap sebagai kunci perubahan menuju arah yang lebih baik.

Pendidikan Islam berwawasan multikultural ditawarkan untuk menjawab pertanyaan seputar membangun kesadaran menerima perbedaan sebagai bentuk kesadaran multikultural. Tulisan ini dibatasi pada penelaahan terhadap hubungan antara pendidikan Islam dan masyarakat multikultural, konsep pembelajaran PAI berwawasan multikultural, dan peran guru Agama Islam dalam pembelajaran pendidikan agama Islam berwawasan multikultural.

\section{B. Pendidikan Islam dan Masyarakat Multikultural.}

Masyarakat Indonesia adalah masyarakat yang pluralistik, serba ganda baik dalam hal etnis, sosial, kultural, politik maupun agama. Masyarakat yang serba ganda ini dituntut untuk selalu hidup rukun, sebab reformasi pembangunan mustahil untuk dilakukan dalam masyarakat yang kacau, dan penuh konflik. Kenyataan menunjukkan kondisi masyarakat yang plural dan multikultur sering memunculkan konflik baik intern maupun ekstern. Belum lagi pengaruh globalisasi yang mempermudah manusia untuk berkomunikasi dengan manusia lain. Akan tetapi di sisi lain globalisasi memunculkan keprihatinan berkenaan dengan pengaruh budaya luar yang berpotensi memarginalkan, bahkan mematikan budaya lokal yang dipercaya mengandung kearifan tradisional. Persoalan globalisasi menjadi persoalan identitas budaya, bagaimana berupaya mempertahankan eksistensi minoritas di dalam mayoritas. Banyak terjadi konflik di sepanjang garis pemisah budaya yang memisahkan peradaban-peradaban, seperti Islam, Kristen, Jepang ,Ortodoks dan lain-lain. Budaya akan menjadi sumber fundamental konflik di dunia setelah sebelumnya dipengaruhi oleh perbedaan ideologi dan ekonomi.

Huntington dalam Fajar (2005:174) mengajukan enam alasan utama kenapa konflik atau benturan dapat terjadi, yaitu:

1. Perbedaan antar peradaban yang riil dan mendasar.

2. Dunia sekarang semakin menyempit, masing-masing individu, peradaban ataupun kelompok berusaha untuk memperkokoh identitasnya, yang pada gilirannya memperkuat perbedaan dan kebencian. 
3. Orang atau masyarakat telah tercerabut dari identitas lokal yang telah mengakar dengan kuat oleh proses modernisasi ekonomi dan perubahan sosial dunia.

4. Adanya peran ganda barat dalam tumbuhnya kesadaran peradaban.

5. Karakteristik dan perbedaan budaya kurang bisa menyatu dan karena itu kurang bisa berkompromi antara karakteristik dan perbedaan poltik dan ekonomi.

6. Regionalisme ekonomi semakin meningkat.

Semua konflik yang muncul ke permukaan, menimbulkan kegetiran terhadap masa depan bangsa Indonesia yang memiliki masyarakat yang plural dan multikultur yang dalam rentang waktu lama telah dipersatukan oleh ikatan kebangsaan yang luhur. Yang paling ironis, agama yang seharusnya dapat menjadi perekat sosial, ternyata malah terperangkap dalam berbagai konflik. Padahal seluruh agama memiliki misi yang suci salah satunya menciptakan kedamaian yang universal.

Agama dalam konteks mikro, dapat diperankan secara positif-konstruktif dalam mempertahankan dan mengembangkan keutuhan yang ditandai dengan keanekaragaman dan kemajemukan. Dalam agama Islam-mengambil sumber dari Al Qur'an terdapat nilai-nilai normatif yang memiliki kaitan dengan persoalan keanekaragaman dan kemajemukan, multikulturalisme dan pluralisme, serta integrasi keduanya.

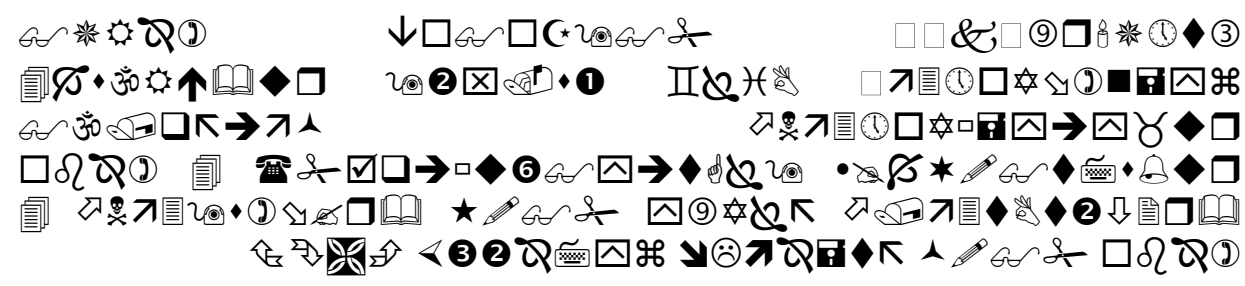

Artinya:"Hai manusia, sesungguhnya kami menjadikan kamu dari laki-laki dan perempuan, dan Kami jadikan kamu berbangsa-bangsa dan bersuku-suku, supaya kamu saling berkenalan. Sesungguhnya orang yang mulia diantara kamu di sisi Allah, adalah orang yang bertaqwa. Suingguh Allah Maha Mengetahui lagi Amat Mengetahui". (Q.S. Al Hujurat, ayat : 13)

Sebagai tempat terjadinya kegiatan pendidikan, masyarakat mempunyai pengaruh besar terhadap berlangsungnya segala kegiatan pendidikan baik yang bersifat formal, informal maupun non formal berisikan generasi muda yang akan 
meneruskan kehidupan masyarakat itu sendiri. Oleh karena itu kegiatan pendidikan harus disesuaikan dengan keadaan dan tuntunan masyarakat (Manan, 2003:155).

Masalah pendidikan tidak akan terlepas dari nilai-nilai kebudayaan yang dijunjung tinggi oleh semua lapisan masyarakat bangsa itu. nilai-nilai itu senantiasa berkembang dan berarti ia mengalami perubahan. Perubahan-perubahan yang terjadi di masyarakat harus diikuti oleh pendidikan agar pendidikan itu tidak ketinggalan zaman. Setiap masyarakat di mana pun tempatnya tentu memiliki ciri-ciri khas yang berbeda dengan masyarakat lain, baik nilai-nilai sosial budaya, pandangan hidup, atau kondisi fisik yang paling mudah dilihat.

Inilah tantangan Pendidikan Islam. Indonesia sebagai negara dengan masyarakat yang multikultural niscaya memerlukan pendidikan agama yang sesuai dengan kondisi multikultural, yakni pendidikan agama yang mampu menumbuhkan kesadaran berbudaya, sadar akan hadirnya berbagai perbedaan kebudayaan dan kesatuan sosial dalam masyarakat Indonesia yang majemuk (Zamroni, 2006: 33). Baik perbedaan yang berdasarkan pada ikatan etnisitas, agama maupun kemampuan kesatuan sosial lainnya. Keragaman budaya Indonesia adalah kekayaan yang harus terus dilestarikan dan diperhatikan sebagai wujud implementasi Bhinneka Tunggal Ika dalam masyarakat. Bhinneka Tunggal Ika merupakan komitmen multikulturalisme yang amat biasa, yang mengakui adanya heterogenitas etnik, budaya agama, gender tetapi menuntut persatuan dalam komitmen politik.

Selain membuka banyak peluang, globalisasi merupakan ancaman yang serius bagi masyarakat yang majemuk. Dis-orientasi, dis-lokasi, atau krisis sosial-budaya di kalangan masyarakat semakin merebak dengan kian meningkatnya penetrasi dan ekspansi budaya barat - khususnya Amerika - sebagai akibat proses globalisasi yang tidak terbendung. Berbagi ekspresi sosial budaya yang sebenarnya asing, tidak memiliki basis, dan presenden kultural semakin menyebar dalam masyarakat, sehingga memunculkan kecenderungan-kecenderungan gaya hidup baru yang tidak selalu sesuai, positif dan kondusif bagi kehidupan sosial budaya bangsa Indonesia (Mahfud,2005: 3).

Berkaca dari problem multikultural dan globalisasi, maka pendidikan Islam harus berfungsi sebagaimana fungsi sistem pendidikan, yakni bersifat stabilitas dan bersifat fluiditas (Ahmadi, 2004:115). Stabilitas berarti Pendidikan Islam tidak berubah atau tidak menginginkan perubahan ini berkaitan dengan ajaran ketauhitan dalam 
Islam. Sedangkan fluiditas bahwa dimungkinkan dalam Pendidikan Islam terjadi perubahan-perubahan, keadaan yang kurang baik harus dirubah menjadi lebih baik.

Pendidikan Islam hendaknya bisa menjadi pendidikan yang berasal dari masyarakat, yakni pendidikan yang memberikan jawaban kepada kebutuhan (needs) dari masyarakat sendiri. Baidhawy (2005: 86) menyebut pendidikan agama untuk masyarakat multikultural dengan pendidikan agama berwawasan multikultural yang menurutnya dialamatkan untuk memenuhi kebutuhan nasional akan pendidikan secara berkesinambungan yang mempresentasikan wajah agama - dan kultural - dan perjumpaannya dalam kesetaraan dan harmoni. Dengan demikian, pendidikan agama menekankan bahwa multikulturalisme merupakan suatu kesempatan dan kemungkinan untuk saling belajar tentang mempersiapkan dan merayakan pluralitas agama - dan etnik serta kultural - melalui dunia pendidikan. Sehingga pada akhirnya kesadaran akan berbudaya dalam keberbedaan akan tercapai.

\section{Pendidikan Agama Islam Berwawasan Multikultural}

Wacana pendidikan multikultural dibahas sebagai satu dinamika pendidikan, sebagian orang mempunyai harapan dan beranggapan bahwa pendidikan multikultural mampu menjadi jawaban dari kemelut dan ruwetnya budaya ciptaan dunia globalisasi, tapi ada pula yang beranggapan bahwa pendidikan ini justru akan memecah belah keragaman, bahkan memandang remeh serta tidak penting karena menganggap sumber daya pendidikan multikultural tidak cukup tersedia. Semua anggapan-anggapan tersebut muncul karena pemaknaan pendidikan multikultural yang sempit. Pendidikan multikultural salah dipahami sebagai pendidikan yang hanya memasukkan isu-isu etnik atau rasial. Padahal yang harus benar-benar dipahami adalah pendidikan multikultural yang mengedepankan isu-isu lainnya seperti gender, keragaman sosial-ekonomi, perbedaan agama, latar belakang dan lain sebagainya. Setiap murid di sekolah datang dengan latar belakang yang berbeda, memiliki kesempatan yang sama dalam sekolah, pluralisme kultural, alternatif gaya hidup, dan penghargaan atas perbedaan serta dukungan terhadap keadilan kekuasaan diantara semua kelompok (Baidhawy, 2005:75)

Dickerson dalam Baidhawy (2005:77) memaknai pendidikan multikutural sebagai : 
"Sebuah sistem pendidikan yang kompleks yang memasukkan upaya mempromosikan pluralisme budaya dan persamaan sosial: program yang merefleksikan keragaman dalam seluruh wilayah sekolah; pola staffing yang merefleksikan keragaman masyarakat, mengajarkan materi yang tidak bias, kurikulum inklusif; memastikan persamaan sumber daya dan program bagi semua siswa sekaligus capaian akademik yang sama bagi semua siswa.

Sebutan lain dari pendidikan multikultural muncul di Irlandia utara, pemerintah menetapkan Education for mutual understanding yang didefinisikan sebagai pendidikan untuk menghargai diri dan menghargai orang lain dan memperbaiki relasi antara orang-orang dari tradisi yang berbeda.

Kebijakan ini sebagai respon dan upaya untuk mengatasi konflik berkepanjangan antara komunitas Katholik (kelompok nasionalis) yang mengidentifikasikan diri dengan tradisi dan kebudayaan Irlandian dengan komunitas Protestan ( kelompok unionis) yang mengidentifikasikan diri dengan tradisi Inggris . Konflik yang muncul pada dekade 60-an merangsang perdebatan di kalangan lembaga-lembaga swadaya masyarakat tentang pemisahan sekolah bagi dua komunitas ini, hal inilah yang melahirkan kebijakan Education for mutual understanding secara formal pada 1989 (Baidhawy,2005:78). Tujuan program ini tidak lain yakni membuat siswa mampu belajar menghargai dan menilai diri sendiri dan orang lain; mengapresiasikan keterkaitan orang-orang dalam masyarakat; mengetahui tentang dan memahami apa yang menjadi milik bersama dan apa yang berbeda dari tradisitradisi kultural mereka; mengapresiasikan bagaimana konflik dapat ditangani dengan cara-cara tanpa kekerasan. Argumen-argumen tentang pentingnya multikulturalisme dan pendidikan multikultural cukup untuk menggantungkan harapan bahwa pembelajaran berbasis multikultural dapat membentuk sebuah perspektif kultural baru yang lebih matang, membina relasi antar kultural yang harmoni, tanpa mengesampingkan dinamika, proses dialektika dan kerjasama timbal balik.

Dalam konteks pendidikan agama, paradigma multikultural perlu menjadi landasan utama penyelenggaraan proses belajar-mengajar. Pendidikan agama membutuhkan lebih dari sekedar transformasi kurikulum, namun juga perubahan perspektif keagamaan dari pandangan eksklusif menuju pandangan multikulturalis, atau setidaknya dapat mempertahankan pandangan dan sikap inklusif dan pluralis.

Disadari atau tidak, kelompok-kelompok yang berbeda secara kultural dan etnik terlebih agama, sering menjadi korban rasis dan bias dari masyarakat yang lebih 
besar. Maka dari itu, Pendidikan Agama Islam sebagai disiplin ilmu yang include dalam dunia pendidikan nasional memiliki tugas untuk menanamkan kesadaran akan perbedaan, mengingat Islam adalah agama mayoritas di Indonesia yang nota bene adalah negara multi-religius.

Pendidikan Agama Islam berwawasan multikultural mengusung pendekatan dialogis untuk menanamkan kesadaran hidup bersama dalam keragaman dan perbedaan, pendidikan ini dibangun atas spirit relasi kesetaraan dan kesederajatan, saling percaya, saling memahami dan menghargai persamaan, perbedaan dan keunikan, serta interdepedensi. Ini merupakan inovasi dan reformasi yang integral dan komprehensif dalam muatan pendidikan agama-agama yang bebas prasangka, rasisme, bias dan stereotip. Pendidikan agama berwawasan multikultural memberi pengakuan akan pluralitas, sarana belajar untuk perjumpaan lintas batas, dan mentransformasi indoktrinasi menuju dialog.

Pendidikan Agama Islam berwawasan multikultural akan lebih mudah dipahami melalui beberapa karakteristik utamanya, yakni: belajar hidup dalam perbedaan, membangun saling percaya (mutual trust), memelihara saling pengertian (mutual understanding), menjunjung sikap saling menghargai (mutual respect), terbuka dalam berpikir, apresiasi dan interdepedensi, resolusi konflik dan rekonsiliasi nirkekerasan (Baidhawy, 2005:58). Dalam situasi konflik, Pendidikan Agama Islam berwawasan multikultural menawarkan angin segar bagi perdamaian dengan menyuntikkan semangat dan kekuatan spiritual, sehingga mampu menjadi sebuah resolusi konflik.

Pendidikan agama Islam berwawasan multikultural merupakan gerakan pembaharuan dan inovasi pendidikan agama dalam rangka menanamkan kesadaran pentingnya hidup bersama dalam keragaman dan perbedaan agama - agama, dengan spirit kesetaraan dan kesederajatan, saling percaya, saling memahami dan menghargai persamaan, perbedaan dan keunikan agama-agama, terjalin dalam suatu relasi dan interdepedensi dalam situasi saling mendengar dan menerima perbedaan perspektif agama-agama dalam satu dan lain masalah dengan pikiran terbuka, untuk menemukan jalan terbaik mengatasi konflik antaragama dan menciptakan perdamaian melalui sarana pengampunan dan tindakan nirkekerasan. 


\section{Peran Guru dalam Pembelajaran PAI Berwawasan Multikultural}

Ada kesan yang memprihatinkan bahwa, "peradaban makin maju, tetapi keberadaban makin mundur". Hampir semua orang bangga dan terkesima oleh perkembangan teknologi dan pembangunan infrastruktur, tetapi di balik itu, umat manusia juga ketakutan terhadap makin merosotnya nilai kemanusiaan yang menggejala di hadapannya.

Dilihat dari kacamata moral, manusia di era globalisasi berada dalam situasi yang cukup mencemaskan. Sebagian anggota masyarakat sekarang tidak lagi bisa membedakan antara merusak dan membangun, susila dan asusila atau kejujuran dan kebohongan. Di lingkungan sekolah, para guru mengeluh atas perilaku para siswanya yang mengalami degradasi atau kemunduran moral mereka kurang memiliki tanggung jawab sebagai pelajar, sopan santun atau perilaku lemah lembut semakin jauh dari perilaku keseharian mereka. Sedangkan di lingkungan luar sekolah, masyarakat mengeluh karena hukum dan etika yang tidak lagi tegak, dan tindakan yang menghalalkan segala cara untuk mencapai tujuan menjadi pandangan yang biasa yang dinikmati sebagian orang dengan tanpa beban.

Sejalan dengan fungsi pendidikan nasional yaitu untuk mengembangkan kemampuan dan membentuk watak serta peradaban bangsa yang bermartabat dalam rangka mencerdaskan kehidupan bangsa serta tujuan pendidikan yaitu untuk mengembangkan potensi peserta didik agar menjadi manusia yang beriman dan bertaqwa kepada Tuhan Yang Maha Esa, berahklak mulia, sehat, berilmu, cakap, kreatif, mandiri, dan menjadi warga negara yang demokratis serta bertanggung jawab, maka pembelajaran PAI berperanan strategis dalam pembentukan moral, ahklak, budi pekerti dan karakter yang baik ( moral and character building). Sementara ukuran kualitas pengalaman belajar PAI itu sendiri selalu berkembang selaras dengan perkembangan tuntutan kebutuhan masyarakat beragama serta tantangan yang dihadapi dalam konteks dan ruang waktu tertentu.

Seorang Guru Pendidikan Agama Islam mau tidak mau harus memahami kecenderungan yang muncul pada era tak terbatasnya teknologi dan komunikasi, yang sebenarnya tidak hanya tantangan seorang guru agama namun juga masyarakat beragama yakni : (1) Internal Diversity atau keragaman internal, (2) structural diferencial atau structural diversity yakni keragaman struktural, (3) Cultural pluralism atau kemajemukan budaya, (4) scientific critism diartikan sebagi kritik ilmu pengetahuan 
terhadap penjelasan agama yang masih konvensional-tradisional (Muhaimin, 2002: $35)$.

Kecenderungan internal diversity, structural diversity dan cultural pluralism mempertegas perlunya upaya pembelajaran PAI yang mampu membentuk kesalehan pribadi dan sekaligus kesalehan sosial pada diri siswa. Tugas seorang GPAI tidak hanya mentransfer ilmu pengetahuan agama kepada peserta didik tapi juga perlu menjaga PAI agar jangan sampai menumbuhkan semangat fanatisme, menumbuhkan sikap intoleran di kalangan masyarakat dan siswa, memperlemah kerukunan hidup beragama serta persatuan dan kesatuan nasional.

Masyarakat Indonesia yang pluralistik, masyarakat yang serba plural, baik dalam agama, etnis, suku, ras, tradisi, budaya dan sebagainya, sangat rentan terhadap timbulnya perpecahan dan konflik-konflik sosial. Karena itu, agama dalam kehidupan masyarakat majemuk dapat berperan sebagai faktor pemersatu (integratif) dan dapat pula berperan sebagai faktor pemecah (disintegratif). Masyarakat plural membutuhkan ikatan keadaban (The bound of civility), yakni pergaulan antara satu sama lain yang diikat dalam suatu "civility" ikatan ini sesungguhnya dapat dibangun dari nilai-nilai ajaran universal agama. Karena itu, GPAI dituntut untuk mampu membelajarkan pendidikan agama yang difungsikan sebagai panduan moral dalam kehidupan masyarakat yang serba plural tersebut. Selain itu GPAI juga diuji kemampuannya untuk mengangkat dimensi-dimensi konseptual dan subtansial dari ajaran agama, seperti kejujuran, keadilan, kebersamaan, kesadaran akan hak dan kewajiban, ketulusan dalam beramal, musyawarah dan sebagainya, untuk diaktualisasikan dan direalisasikan dalam hidup dan kehidupan masyarakat yang plural tersebut (Muhaimin, 2002: 35).

Namun demikian paradigma keberagamaan masyarakat masih tergolong ekslusif, pemahaman ini tidak bisa dipandang sebelah mata karena selain menjadi salah satu faktor penyebab konflik, pemahaman ini dapat membentuk pribadi yang antipati terhadap pemeluk agama lainnya. Pribadi yang tertutup dan menutup ruang dialog dengan agama lainnya. Pribadi yang merasa agama dan alirannya saja yang paling benar sedangkan agama dan aliran lainnya adalah salah dan bahkan dianggap sesat yang lebih lanjut lagi akan memunculkan sikap memusnahkan dan merusak agama atau aliran lain. 
Menurut Muhammad Ali dalam Yaqin (2005:57) untuk mencegah pemahaman keberagamaan masyarakat yang eksklusif ini agar tidak terus berkembang, maka perlu diambil beberapa langkah preventif. Langkah yang perlu dilakukan adalah pembangunan pemahaman keberagamaan yang lebih inklusif-pluralis, multikultural, humanis, dialogis-persuasif, kontekstual, subtantif, dan aktif sosial yang dikembangkan melalui pendidikan, media masa dan interaksi sosial.

Paradigma keberagamaan inklusif-pluralis berarti dapat menerima pendapat dan pemahaman agama lain yang memiliki basis ketuhanan dan kemanusiaan. Pemahaman keberagamaan yang multikultural berarti menerima adanya keragaman ekspresi budaya yang mengandung nilai-nilai kemanusiaan dan keindahan. Sedangkan pemahaman yang humanis adalah mengakui pentingnya nilai-nilai kemanusiaan dalam beragama yang artinya seseorang yang beragama harus dapat mengimplementasikan nilai-nilai kemanusiaan; menghormati hak azasi orang lain, peduli terhadap orang lain dan berusaha membangun perdamaian dan kedamaian bagi seluruh umat manusia.

Paradigma dialogis-persuasif berarti lebih mengedepankan dialog dan cara-cara damai dalam melihat perselisihan dan perbedaan pemahaman keagamaan daripada melakukan tindakan-tindakan fisik seperti teror, perang, dan bentuk kekerasan yang lain. Paradigma kontekstual berarti menerapkan cara berpikir kritis dalam memahami teks-teks keagamaan yang tidak bisa diganggu gugat akan tetapi tidak sedikit dari teks-teks keagamaan tersebut yang membutuhkan intrepetasi-intrepretasi kritis dalam upaya untuk menjawab permasalahan-permasalahan keagamaan terkini.

Sedangkan paradigma subtantif adalah mementingkan dan menerapkan nilainilai agama daripada hanya melihat dan mengagungkan simbol-simbol keagamaan. Paradigma pemahaman aktif sosial berarti agama tidak hanya menjadi alat pemenuhan kebutuhan rohani secara pribadi saja. Akan tetapi yang terpenting adalah membangun kebersamaan dan solidaritas bagi seluruh umat manusia melalui aksi-aksi sosial yang nyata yang dapat meningkatkan kesejahteraan umat manusia.

Dengan membangun paradigma pemahaman keberagamaan yang lebih humanis, pluralis, dan kontekstual diharapkan nilai-nilai universal yang ada dalam agama seperti kebenaran,keadilan, kemanusiaan, perdamaian dan kesejahteraan umat manusia dapat ditegakkan. Lebih khusus lagi, agar kerukunan dan kedamaian antar umat beragama dapat terbangun. 
Orientasi pendidikan yang tidak hanya mengacu pada pembentukan pemahaman keagamaan secara tekstual dan ritual, tapi juga mengacu pada pemahaman yang kontekstual dan sosial. Kurikulum yang tidak hanya bertujuan membangun kemampuan siswa terhadap mata pelajaran keagamaan, tapi juga bagaimana membangun sikap siswa yang agamis dan peduli.

Guru merupakan faktor penting dalam pengimplementasian nilai-nilai keagamaan yang inklusif dan moderat di sekolah. Guru mempunyai peran penting dalam pendidikan agama berwawasaan multikultural karena ia merupakan salah satu target dari strategi pendidikan tersebut. Apabila seorang guru memiliki paradigma keberagamaan yang inklusif dan moderat, maka ia juga akan mampu untuk mengajarkan dan mengimplementasikan nilai-nilai keberagamaan tersebut terhadap siswanya di sekolah.

Menjadi seorang guru agama yang berwawasan multikultural dituntut untuk hati-hati dalam memberikan analisis suatu masalah. Misalnya saja pada gambaran masalah berikut ini :

"Seorang guru yang beragama A, sedang memberikan penjelasan bahwa krisis ekonomi pada tahun 1997 yang dialami oleh hampir keseluruhan negara-negara di benua $X$ merupakan akibat dari konspirasi perdagangan pengusaha kelas dunia dari negara $Y$ yang notabene beragama B, lebih lanjut lagi dia menjelaskan bahwa para pengusaha tersebut sengaja menciptakan krisis di benua $X$ yang mayoritas penduduknya beragama $A$, agar masyarakat yang beragama $A$ selalu berada di bawah kontrol negara dari agama $B^{\prime \prime}$.

Penjelasan dari guru agama semacam ini merupakan tindakan yang tergolong provokatif, karena dapat membangkitkan kebencian siswa terhadap para pemeluk agama tertentu. Apabila seorang guru agama tidak mempunyai argumentasi atau alasan yang bisa dipertanggungjawabkan, seharusnya ia tidak memberikan penjelasan yang dapat merusak kepercayaan siswa terhadap orang yang berbeda yang berada di lingkungan sekitarnya.

Menurut sebagian besar hasil penelitian terhadap berbagai kasus sosial, budaya, dan politik, kasus-kasus seperti yang tersebut di atas lebih dilatarbelakangi oleh adanya kepentingan politik dan ekonomi. Agar kasus seperti demikian tidak terjadi, menurut Ainul Yaqin penting bagi seorang guru agama untuk memahami perannya dan mempunyai wacana keberagamaan yang moderat yaitu guru agama yang tidak mudah menyalahkan pemeluk agama lain (Yaqin, 2005:60). 
Peran guru agama dalam pengimplementasian nilai-nilai keberagamaan yang moderat meliputi: pertama, menyelenggarakan proses pembelajaran yang demokratis dan objektif di dalam kelas. Artinya segala tingkah lakunya, baik sikap dan perkataannya, tidak diskriminatif (bersikap adil dan tidak menyinggung) anak didik yang berbeda dalam paham keberagamaannya, misal dari keberagaman internal dalam agama ( NU, Muhammadiyah) atau bahkan agama lain. Kedua, menyusun rencana atau rancangan pembelajaran yang bertujuan mengarahkan anak didik untuk memiliki kepedulian yang tinggi terhadap kejadian-kejadian tertentu yang ada hubungannya dengan agama, contohnya saat terjadi bom Bali pada tahun 2003. Jika ia seorang guru agama yang berwawasan multikultural maka ia akan menunjukkan keprihatinannya terhadap peristiwa tersebut dan menjelaskan bahwa jalan kekerasan tidak akan pernah menyelesaikan suatu masalah malah akan menimbulkan masalah baru yang lebih berat (Muhaimin, 2002:59). Berkaitan dengan hal ini, guru agama harus menjelaskan bahwa inti dari ajaran agama Islam adalah menciptakan kedamaian dan kesejahteraan bagi seluruh umat manusia. Pemboman, invasi militer dan segala bentuk kekerasan adalah sesuatu yang dilarang dalam agama. Sebagai jawaban, dialog dan musyawarah adalah cara yang tepat untuk menyelesaikan masalah yang sangat dianjurkan di dalam agama Islam demikian pula dengan agama-agama yang lain.

Kemajuan teknologi diperbagai bidang, mendorong masuknya kebudayaan luar ke tanah air dengan hampir tidak dapat terbendung. Desakan budaya luarbudaya non Islam- yang sedemikian rupa mendorong kita untuk melakukan proses belajar antar budaya ataupun antar peradaban, sehingga unsur-unsur kebudayaan asing dapat diterima dan diolah ke dalam kebudayaan sendiri (Muhaimin, 2002:60). Proses ini didorong oleh ajaran Islam yang : (1) menghormati akal manusia, (2) mewajibkan umatnya untuk menuntut ilmu dan berdo'a agar ilmu mereka bertambah; (3) melarang taqlid buta; (4) menggalakkan daya inisiatif;(5) menyuruh mempergunakan hak atas keduniaan untuk mencapai kesejahteraan di dunia dan di akhirat;(6) menganjurkan memperluas pengalaman dan pergaulan; (7) memerintahkan bersikap kritis atas segala sesuatu; (8) menitahkan sikap terbuka dan berlapang dada; (9) menitahkan hidup yang berkeseimbangan. Hal ini menuntut seorang guru agama untuk bersikap proporsional terhadap kebudayaan yang artinya ia harus mampu memelihara unsur nilai dan norma kebudayaan yang sudah ada, yang bersifat positif; menghilangkan unsur nilai dan norma kebudayaan yang nilainya negatif; 
menumbuhkan unsur nilai dan norma yang belum ada, yang bersifat positif; bersikap receptive (menerima), selective, digestive (mencernakan), assimilative (menggabungkan dalam suatu sistem), dan transmissive terhadap kebudayaan pada umumnya; dan melakukan penyucian atas kebudayaan, agar sesuai atau tidak bertentangan dengan nilai-nilai dan norma-norma Islam. hal ini mengandung makna bahwa setiap guru agama Islam dituntut untuk menjadi aktor beragama yang loyal, concern dan commitment dalam menjaga dan memelihara ajaran dan nilai-nilai Islam dalam segala aspek kehidupan.

Seorang guru agama Islam bertanggung jawab atas religiusitas anak didiknya meski tidak secara penuh -masih ada orang tua dan diri anak sendiri- oleh karena itu penting bagi seorang guru agama Islam untuk menciptakan suasana yang religius baik bersifat vertikal yang diwujudkan dalam bentuk kegiatan-kegiatan ritual, seperti shalat berjama'ah, puasa senin-kamis, do'a bersama ketika akan dan telah meraih sukses tertentu, menegakkan komitmen dan loyalitas terhadap moral force di sekolah dan lain-lain. Kegiatan-kegiatan ritual yang merupakan bentuk dari habl min Allah tersebut akan selalu memiliki konsekuensi horisontal dan sosial. Seseorang yang hanya mementingkan ritual atau hubungan vertikal dengan Tuhannya dari pada hubungan horisontal atau sosial maka ia lebih mementingkan kesalehan individu, atau terjebak dalam hedonisme spiritual yang hanya memberikan manfaat untuk dirinya sendiri dan bukan termasuk ahli manfaat. Untuk menciptakan suasana religius di sekolah dapat dilakukan melalui pendekatan pembiasaan, keteladanan, dan pendekatan persuasif atau mengajak kepada warganya dengan cara halus, dengan memberikan alasan dan prospek baik yang bisa meyakinkan mereka.

Muhadjir dalam Muhaimin (2002:140) menyatakan bahwa kompleksitas kehidupan pluralistik menuntut seseorang untuk tidak menampilkan konstruk yang closed ended. Seorang guru agama harus terus mengembangkan kesadaran multikulturalis anak didiknya. Sikap yang multikulturalis dalam hidup bukanlah mengajak orang untuk beragama dengan jalan sinkritisme, memaknai bahwa semua agama sama atau berusaha mencampur baurkan segala agama menjadi satu. Dan bukan pula mengajak seseorang untuk melakukan sintesis dalam beragama atau menciptakan agama baru tapi sikap multikulturalis yang dimaksud adalah sikap yang setuju dengan adanya perbedaan (agree in disagreement) ia yakin bahwa agama yang ia 
peluk itulah agama yang paling benar dan baik, namun demikian diantara agama yang satu dengan yang lainnya di samping terdapat perbedaan juga terdapat persamaan.

Ketika menjalankan tugasnya di dalam kelas, seorang guru agama akan dihadapkan pada keragaman pengetahuan, latar belakang, pengamalan dan pengalaman serta persepsi keberagamaan anak didik. Sebagaimana diketahui anak didik dalam satu kelas maupun lingkungan sekolah memiliki keragaman. Artinya kondisi yang satu dengan yang lain belum tentu sama, apalagi dalam beragama, kita tidak mungkin terbebas dari pengaruh-pengaruh paham keagamaan yang hidup di tengah-tengah masyarakat. Sebagai contoh dalam Islam kita mengenal paham ahlu sunnah wal jama'ah dan ada yang tidak. Dengan demikian dalam menjalankan tugas dan peran utamanya itu guru agama tidak hanya menguasai bahan dan didaktik metodik,melainkan menuntut kesiapan serta kematangan pribadi dan wawasan keilmuwan yang luas, dalam lingkungan yang multikultural, seorang guru agama sebagai komunikator harus mampu menghadapi keragaman yang ada di lingkungan sekolah dengan profesional dan proporsional.

\section{E. Penutup}

Penulis berfikir bahwa, Indonesia sebagai negara dengan masyarakat yang multikultural niscaya memerlukan pendidikan agama yang sesuai dengan kondisi multikultural, yakni pendidikan agama yang mampu menumbuhkan kesadaran berbudaya, sadar akan hadirnya berbagai perbedaan kebudayaan dan kesatuan sosial dalam masyarakat Indonesia yang majemuk. Pendidikan Islam harus bersifat stabilitas, yang berarti tidak berubah atau tidak menginginkan perubahan, ini berkaitan dengan ajaran ketauhitan dalam Islam, dan bersifat fluiditas, artinya dalam pendidikan agama Islam dimungkinkan terjadi perubahan-perubahan. Pendidikan Islam hendaknya bisa menjadi pendidikan yang berasal dari masyarakat, yakni pendidikan yang memberikan jawaban kepada kebutuhan (needs) dari masyarakat sendiri.

Pembelajaran Pendidikan Agama Islam berwawasan multikultural diharapkan dapat membentuk perspektif kultur Islam yang baru dan lebih matang, membina relasi antar kultur Islam yang harmonis, tanpa mengesampingkan dinamika, proses dialektika dan kerjasama timbal balik. Paradigma multikultural perlu diposisikan sebagai landasan utama penyelenggaraan pembelajaran yang memiliki beberapa 
pendekatan untuk mengintegrasikan dan mengembangkan perspektif multikultural, yakni mempromosikan konsep diri yang positif, memberikan pengayaan literaturliteratur Islam yang bermuatan pengetahuan Islam yang plural ataupun multikultural kepada anak didik. Pendidikan Agama Islam dalam pendidikan multikultural tidak semata menyentuh proses pemindahan pengetahuan (transfer of knowledge), namun juga membagi pengalaman dan ketrampilan (sharing experience and skill). Pembelajaran pendidikan agama Islam berwawasan multikultural mengajarkan tentang kerukunan atau toleransi dan demokrasi.

Jadi, peran guru agama dalam pembelajaran Pendidikan Agama Islam berwawasan multikultural yaitu:

1. Menyelenggarakan proses pembelajaran yang demokratis dan objektif di dalam kelas. Artinya segala tingkah lakunya, baik sikap dan perkataannya, tidak diskriminatif (bersikap adil dan tidak menyinggung) anak didik yang berbeda dalam paham keberagamaannya.

2. Menyusun rencana atau rancangan pembelajaran yang bertujuan mengarahkan anak didik untuk memiliki kepedulian yang tinggi terhadap kejadian-kejadian tertentu yang ada hubungannya dengan agama.

3. Menciptakan suasana yang religius baik bersifat vertikal yang diwujudkan dalam bentuk kegiatan-kegiatan ritual.

4. Mengembangkan kesadaran multikulturalis anak didiknya.

5. Bertindak sebagai komunikator dalam menciptakan suasana keagamaan individu-individu maupun kelompok lingkungan anak didik dan mampu menghadapi keragaman yang ada di lingkungan sekolah dengan profesional dan proporsional.

\section{F. Daftar Pustaka}

Ahmadi, Abu. (2004). Sosiologi Pendidikan. Jakarta : PT. Rineka Cipta.

Baidhawy, Zakiyuddin. (2005). Pendidikan Agama Berwawasan Multikultural. Jakarta: Erlangga.

Fajar, A.Malik. (2005). Holistika Pemikiran Pendidikan. Jakarta: Raja Grafindo Persada.

Hilmy, Masdar. (2003). Menggagas Paradigma Pendidikan Berbasis Multikulturalisme. Jurnal Ulumuna, Volume VII. Edisi 12 Nomor 2 Juli-Desember 2003.

Mahfud, Choirul. (2005) ."Mewujudkan Kesetaraan Budaya”, Jawa Pos, 26 Februari 2005.

Manan, Abdul. (2003). Masyarakat Sebagai Salah Satu Lingkungan Pendidikan. Malang: IKIP Malang. 
M.A et. al. (2002). Paradigma Pendidikan Islam: Upaya Mengefektifkan Pendidikan Agama Islam di Sekolah. Cet. II. Jakarta : PT. Remaja Rosda Karya

. (2002).Paradigma Pendidikan Islam : Upaya mengefektifkan Pendidikan Agama Islam di Sekolah. Bandung: Remaja Rosda Karya.

Muhaimin. (2002). Paradigma Pendidikan Islam: Upaya Mengefektifkan Agama Islam Di Sekolah, Cet. II, Jakarta: PT. Remaja Rosda Karya

Yaqin, M. Ainul. (2005). Pendidikan Multikultural : Cross-Cultural Understanding untuk Demokrasi dan Keadilan. Yogyakarta: Pilar Media

Zamroni, A. (2006). Pendidikan Kecakapan Hidup dan Kesadaran Budaya. MPA No. 239 Th. XX Agustus 2006. 